\title{
Et varselrop om læringsmiljøet i klinikken
}

Ingrid Neteland gir en urovekkende beskrivelse av hvordan hun opplever tilværelsen som medisinstudent. Det som i hovedsak burde være en god opplevelse av læring og personlig vekst, er blitt en kamp for å bevare selvrespekt og selvtillit. Hun er neppe alene blant medisinstudenter om opplevelse av manglende mestring, men er kanskje modigere enn de fleste siden hun tør eksponere sin frustrasjon og usikkerhet. Hvorfor opplever hun det slik? Hun nevner selv mulige individuelle årsaker, og dessverre rettes ofte oppmerksomheten ensidig mot dem når vi som lærere står overfor slike beretninger. Men Ingrid Neteland er ikke villig til å påta seg alt ansvar - og hvorfor skulle hun det? Hun er sikkert mer enn godt nok intellektuelt utrustet til å mestre medisinstudiet, hun er etter alt å dømme motivert og tar studiene og sitt fremtidige yrke på alvor (ellers hadde hun neppe skrevet innlegget). Når hun så likevel opplever lite mestring, synkende selvtillit og skuffelse, er det grunn til å ta det på alvor og ikke umiddelbart avfeie det som «hennes problem».

Ingrid Netelands historie handler dypere sett om et læringsmiljø som - i alle fall for henne - har alvorlige mangler. Hennes historie bør få alle som er involvert i medisinsk grunnutdanning til å tenke over hva som kjennetegner et godt læringsmiljø, og om det miljøet de selv er en del av, oppfyller de viktigste kriteriene (1). Min påstand er at kvaliteten på den kliniske undervisningen er truet, og at trusselen er økende.

Ingrid Neteland forteller om et miljø preget av utrygghet. Hennes forventninger til klinikken ble ikke innfridd, tvert imot opplever hun nederlag og møter liten interesse fra sine lærere. Et godt læringsmiljø kjennetegnes blant annet av tillit mellom studenter og lærere. Tillit bygges over tid, og krever at student-lærer-kontakten er av en viss varighet. Mangel på kontinuitet er et hovedproblem ved dagens studier (2). For Ingrid Neteland var opplevelsen med én veileder gjennom nevrologiterminen kanskje grunnen til at hun likte faget.

Et annet problem hun opplever, er uklare forventninger om mestringsnivå. Hva er egentlig godt nok? «Kanskje har jeg altfor høye krav til hva jeg kan forvente av mestringsfølelse på dette studiet?» Ja, hvis studentene opplever et usagt (og urealistisk) krav om full mestring samtidig som veiledningen er mangelfull, er det ikke rart de blir usikre. En spørreundersøkelse utført i 2006 blant 531 medisinstudenter fra alle de fire fakultetene (3) viste at over $70 \%$ mente det var behov for bedre veiledning og mer tilbakemelding i den kliniske undervisningen.

Problemene er nok noe forskjellige ved de forskjellige universitetssykehusene, men felles synes å være en nedprioritering av utdanningsoppgavene. Jeg tror at hvis man undersøkte hvor universitetsansatte og andre leger ved universitetssykehusene har sin oppmerksomhet, kommer utdanning langt ned på listen. Det er mange grunner til det - økonomistyring, dysfunksjonelle omorganiseringer, underbemanning og annet - men ansvaret for utdanningskvaliteten ligger uansett på oss.

Hvis ikke fakultetene og den enkelte lærer tar ansvar, setter vi oss i en posisjon hvor fakultetene etter hvert mister sin autonomi når det gjelder utdanningen. Hvis ikke universitetssykehusenes ledelse ser sitt ansvar for utdanningen, er det universitetene og de medisinske fakultetene som må gå $\mathrm{i}$ krigen. Ingen kommer til å gjøre det for oss.

\section{Per Brodal}

p.a.brodal@medisin.uio.no

Institutt for medisinske basalfag

Universitetet i Oslo

Per Brodal (f. 1944) er professor emeritus i medisin (anatomi) med spesialkompetanse innen nevrobiologi og medisinsk utdanning. Forfatter har fylt ut ICMJE-skjemaet og oppgir ingen interessekonflikter.

Litteratur

1. Raaheim A. Læring og undervisning. Bergen: Fagbokforlaget, 2010

2. Haidet P, Stein HF. The role of the student-teacher relationship in the formation of physicians. The hidden curriculum as process. J Gen Intern Med 2006; 21 (Suppl 1): S16-20.

3. Danielsson K, Wiggen N. Fra bok til sengekant. Hvordan underviser våre fire universiteter i klinisk medisin? Oslo: Det medisinske fakultet, Universitetet i Oslo, 2006.

Mottatt 2.3. 2012 og godkjent 5.3. 2012. Medisinsk redaktør Erlend Hem. 